\title{
AKTIVITAS ANTIBAKTERI EKSTRAK ETANOL DAUN DAN KULIT BATANG BERENUK TERHADAP Bacillus cereus
}

\author{
Devi Nisa Hidayati ${ }^{* 1)}$, Cicih Sumiarsih ${ }^{2)}$, Umroh Mahmudah ${ }^{2)}$, Anita Dwi Puspitasari ${ }^{2)}$ \\ 1,2. 3,4 Fakultas Farmasi Universitas Wahid Hasyim \\ Jl. Menoreh Tengah X/22, Sampangan, Semarang \\ Email: devinisahidayati@unwahas.ac.id
}

\section{INTISARI}

Tanaman berenuk (Crecentia cujete Linn.) diketahui memiliki aktivitas antibakteri dan dapat digunakan sebagai obat diare akibat mikroorganisme. Bacillus cereus salah satu bakteri penyebab diare. Tujuan penelitian untuk mengukur daya hambat terhadap Bacillus cereus yang disebabkan oleh ekstrak etanol daun (EDB) dan kulit batang berenuk (EKB). EDB dan EKB diekstraksi dengan etanol 96\% menggunakan metode maserasi. Uji antibakteri EEDKB dilakukan dengan metode disk diffusion pada EDB konsentrasi 30\%, 60\%, 90\%, 120\% dan 150\% , serta pada EKB menggunakan konsentrasi 60\%, 70\%, 80\%, 90\% dan 100\% kemudian dilakukan pengukuran aktivitas antibakteri dengan melihat Diameter Daerah Hambat (DDH). Hasil uji aktivitas antibakteri EEDKB membuktikan bahwa EDB dan EKB terbukti mampu menghambat pertumbuhan Bacillus cereus.

Kata Kunci: Antibakteri, Crescentia cujete Linn, Bacillus cereus.

\begin{abstract}
The plants (Crecentia cujete Linn) Are known to have antibacterial activity and can be used as a diarrhea drug due to microorganisms. Bacillus cereus is one of the bacteria that causes diarrhea.This aims to the study was antibacterial activity of ethanol extract of leaves (EL) and bark broodstock (EB) on Bacillus cereus. EL and EB were extracted with ethanol $96 \%$ using maceration method. Antibacterial activity test was carried out with disk diffusion method in EL with a concentration of 30\%,60\%, 90\%, $120 \%$ and $150 \%$, and in EB using concentrations of $60 \%, 70 \%, 80 \%, 90 \%$ and $100 \%$ then antibacterial activity measurements were taken. by looking at the Diameter of the Inhibitory Area (DDH). The results of the EL and EB of antibacterial activity proved that EL and EB berenuk have antibacterial activity against Bacillus cereus.
\end{abstract}

Keywords: Antibacterial, Crescentia cujete Linn, Bacillus cereus.

Corresponding author:

Devi Nisa Hidayati

Fakultas Farmasi Universitas Wahid Hasyim

JL. Menoreh Tengah IX/22 Sampangan Semarang

Email: devinisahidayati@unwahas.ac.id

\section{PENDAHULUAN}

Infeksi di Indonesia termasuk sepuluh penyakit memiliki angka kematian yang cukup tinggi. Penyakit tersebut salah satunya disebabkan akibat adanya bakteri yang bersifat patogen (Darmadi, 2008). Salah satunya disebabkan oleh bakteri penyebab diare. Survei morbiditas yang dilakukan Departemen Kesehatan (2000) sebanyak 301/1000 sampai tahun 2010 angka kejadiannya sebesar 411/1000 survei mortalitas akibat diare menempati urutan ke 13 dengan proporsi kematian 3,5\% (Kemenkes, 2011).

Daun berenuk mengandung senyawa fenolik yang terbukti mampu mempengaruhi penghambatan pertumbuhan bakteri S. aureus dan E. coli (Ardianti dan Kusnadi, 2014). Menurut Rinawati (2011) ekstrak etanol dari daun, kulit batang serta buah yang segar atau kering berenuk (Crescentia cujete Linn.) memiliki daya antibakteria terhadap bakteri Vibrio alginolitycus. Agarwal dan Chaulan (2015) menyatakan bahwa ekstrak air dan ekstrak etanol dari kulit batang dan daun 
berenuk dapat menghambat pertumbuhan bakteri Mycobacterium tuberculosis. Melihat potensi daun dan kulit batang berenuk sebagai antibakteri maka perlu diketahui aktivitas antibakteri terhadap bakteri lain yang diduga mengakibatkan diare seperti Bacillus cereus.

\section{METODE PENELITIAN}

Bahan Penelitian

Bahan yang digunakan untuk memperoleh ekstrak adalah daun dan kulit batang berenuk yang didapat dari perkebunan Watu Simbar, Kecamatan Gunung Pati, Kabupaten Semarang masing-masing sebanyak $15 \mathrm{~kg}$ bahan segar yang dipanen pada pagi hari dengan pengambilan secara random. Bahan kimia yang digunakan etanol 96\% teknis diperoleh dari PT. Bratacem Tbk, silika pengering dari PT. Bratacem Tbk dan aquadest, Bacillus cereus nutient broth (NB) dan nutrien agar (NA) DMSO dan kloramfenikol $30 \mu \mathrm{g} /$ disk.

\section{Alat Penelitian}

Timbangan (Henher Scale), neracaanalitik (Ohauss), rotaryevaporator (Heidolph), moisture contente balance (Ohauss), ayakanno. 40, oven, vaccum, cawan petri, Laminar Air flow,jarum ose, lampu spiritus, inkubator, autoklaf, tabung reaksi, micropipet, blue tip, paper disc, jangka sorong dan vortex.

\section{JALANNYA PENELITIAN}

\section{Identifikasi Tanaman Berenuk (Determinasi)}

Proses identifikasi tanaman dilakukan untuk menyakinkan bahwa identitas tanaman yang digunakan dalam penelitian benar tanaman berenuk. Tahapan tersebut dilakukan dengan melihat ciri-ciri dari bagian tanaman baik daun, batang, bunga sesuai dengan literatur.

\section{Pembuatan Simplisia, EDB serta EKB.}

Tanaman berenuk bagian daun dan kulit batang segar, dicuci sebelum dikeringkan. Pengeringan dilakukan menggunakan oven pada suhu $50^{\circ} \mathrm{C}$, dilanjutkan proses penyerbukan. Sebanyak 2000 gram serbuk direndam pelarut (10:1) yaitu dengan $20 \mathrm{~L}$ etanol $96 \%$ untuk proses maserasi dan remaserasi. Proses maserasi membutuhkan pelarut sebanyak $15 \mathrm{~L}$ dengan merendam serbuk selama 3 hari sesekali dilakukan pengadukan dua kali dalam satu hari. Selanjutnya, sari dan ampas disaring dengan corong buchner hingga didapat maserat (Filtrat I). Lalu, dilakukan remaserasi dengan cara menambahkan etanol $96 \%$ sebanyak $5 \mathrm{~L}$ pada ampas. Sari dan ampas disaring dengan corong buchner hingga didapat Filtrat II. Maserat yang didapat (Filtrat I dan Filtrat II) dicampur hingga homogen. Selanjutnya, maserat dikentalkan hingga mendapatkan ekstrak kental.

\section{Uji Antibakteri Ekstrak Daun dan Kulit Batang Berenuk}

Pengujian antibakteri menggunakan metode disc diffusion (Kirby Bauer). Suspensi bakteri 1 $\mathrm{mL}$ dicampurkan kedalam $15 \mathrm{~mL}$ nutrien agar kemudian dihomogenkan dan dituangkan pada petri disk (Sa'diyah, 2012). EDB dan EKB dengan masing-masing konsentrasi diteteskan pada disk, kemudian diplotkan pada media pertumbuhan nutrien agar yang telah memadat. Media tersebut diinkubasi selama 24 jam menggunakan suhu $37^{\circ} \mathrm{C}$. Berikutnya dilakukan pengukuran daerah hambat bakteri (DDH).

\section{ANALISIS DATA} $\mathrm{DDH}>6 \mathrm{~mm}$.

Hasil DDH uji aktivitas diukur setelah 24 jam inkubasi. Dikatakan memiliki aktivitas apabila

\section{HASIL DAN PEMBAHASAN}

\section{A. Pembuatan Simplisia dan Ekstrak Daun Berenuk (EDB) dan Ekstrak Kulit Batang Berenuk (EKB)}

Pembuatan serbuk simplisia didahului dengan pengeringan daun dan kulit batang berenuk. Pengeringan dilakukan dengan cara pemanasan pada suhu $50^{\circ} \mathrm{C}$, sampai kadar air simplisia mencapai kurang dari 10\% (BPOM RI, 2014). Proses tersebut untuk menjaga kualitas dari simplisia agar mampu disimpan dalam waktu lama. Selain itu juga, proses pengeringan dapat 
terhindar dari kapang dan bakteri pada saat penyimpanan. Kadar air yang tinggi dalam simplisa akan mempengaruhi mutu dan kualitas suatu simplisia. Simplisia yang telah kering, kemudian dihaluskan dan diayak agar ukuran partikelnya menjadi lebih kecil sehingga dapat meningkatkan zat aktif yang tersari.

Metode maserasi merupakan metode penyarian senyawa bahan alam dengan cara dingin, sehingga dipilih agar senyawa polifenol yang diduga berpotensi sebagai zat antibakteri dari daun berenuk tidak mengalami kerusakan karena adanya pemanasan. Metode maserasi juga merupakan metode yang sederhana dan tidak membutuhkan alat khusus seperti metode perkolasi maupun soxletasi. Pelarut yang dipilih adalah etanol 96\%. Pelarut etanol 96\% lebih dipilih karena salah satu pelarut yang digunakan dalam bahan baku pembuatan sediaan herbal. Ekstrak daun dan kulit batang berenuk telah dilakukan standarisasi ekstrak, walaupun hasil yang didapat belum semua parameter memenuhi persyaratan standarisasi (Hidayati et al, 2018).

\section{B. Hasil Uji Aktivitas Antibakteri EEDKB terhadap Bacillus cereus.}

Pengujian kemampuan penghambatan bakteri Bacillus cereus dilakukan menggunakan metode Disc diffusion yang merupakan suhu dan waktu yang paling optimal untuk pertumbuhan bakteri. Pengujian aktivitas menggunakan EDB pada konsentrasi 30\%, 60\%, 90\%, 120\% dan $150 \%$ dan EKB pada konsentrasi 60\%, 70\%, 80\%, 90\% dan 100\%. Pelarut ekstrak dan kontrol negatif (dimethyl sulfoxide/DMSO). Hasil pengujian aktivitas antibakteri EDB dan EKB terhadap Bacillus cereus (Gambar 1).

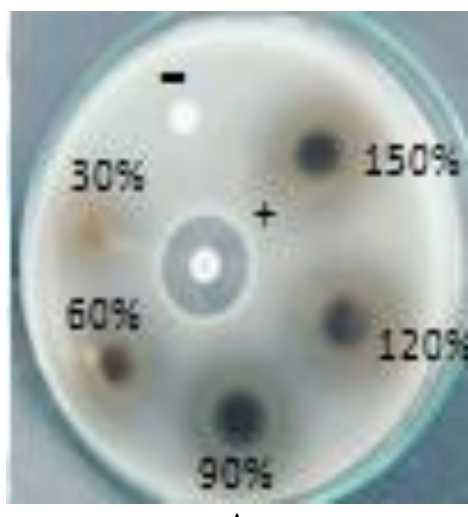

A

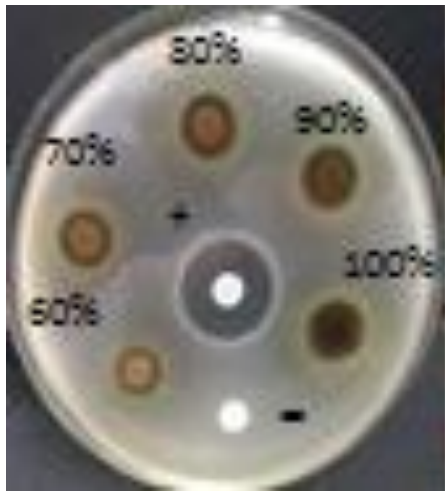

$\mathrm{B}$

\section{Gambar 1. Hasil Pengujian Aktivitas Antibakteri EDB (A) dan EKB (B) terhadap Bacillus cereus}

Senyawa metabolit sekunder dari daun berenuk yang terbukti sebagai antibakteri menurut Ardianti dan Kusnadi (2014) yaitu senyawa fenolik, senyawa tersebut berpotensi sebagai antibakteri dengan merusak membran sel bakteri. Sedangkan pada kulit batang berenuk menurut Rosdiana (2016) mengandung alkaloid, flavonoid, saponin, tanin dan steroid. Pengujian aktvitas antibakteri EDB dan EKB terhadap Bacillus cereus menunjukan aktivitasnya pada semua konsentrasi dengan pengamatan uji aktivitas EDB dan EKB (Tabel I).

Kontrol positif yang dipilih adalah klorampenikol yang bersifat bakteriostatik berspektrum luas sehingga efektif dalam membunuh/menghambat bakteri gram positif dan negatif serta merupakan antibiotik yang sering digunakan pada terapi diare akut (Agitsah et al, 2014). Mekanisme kerja klorampenikol sebagai antibakteri yaitu mengakibatkan penghambatan ikatan protein dengan pengikatan ribosom pada bakteri (Ganiswara, 1995). 
Tabel I. Uji Aktivitas Antibakteri EDB dan EKB terhadap Bacillus cereus

\begin{tabular}{|c|c|c|c|c|c|}
\hline \multirow{9}{*}{ EDB } & \multirow{2}{*}{ Perlakuan } & \multicolumn{3}{|c|}{ Diameter Daerah Hambat (DDH) (mm) } & \multirow{2}{*}{ Rata-rata $\pm \mathrm{SD}(\mathrm{mm})$} \\
\hline & & $\mathrm{I}$ & II & III & \\
\hline & $30 \%$ & 7,715 & 7,78 & 7,14 & $7,545 \pm 0,35$ \\
\hline & $60 \%$ & 8,03 & 8,18 & 8,72 & $8,31 \pm 0,36$ \\
\hline & $90 \%$ & 9,80 & 10,05 & 9,35 & $9,73 \pm 0,35$ \\
\hline & $120 \%$ & 10,14 & 10,10 & 10,25 & $10,16 \pm 0,07$ \\
\hline & $150 \%$ & 11,25 & 11,06 & 11,70 & $11,33 \pm 0,32$ \\
\hline & $(+)$ & 18,14 & 17,74 & 17,61 & $17,84 \pm 0,27$ \\
\hline & $(-)$ & - & - & - & - \\
\hline \multirow{9}{*}{$\mathrm{EKB}$} & \multirow{2}{*}{ Perlakuan } & \multicolumn{3}{|c|}{ Diameter Daerah Hambat (DDH) (mm) } & \multirow{2}{*}{ Rata-rata \pm SD $(\mathrm{mm})$} \\
\hline & & $\mathrm{I}$ & II & III & \\
\hline & $60 \%$ & 10,6 & 10,2 & 10,7 & $10,5 \pm 0,26$ \\
\hline & $70 \%$ & 11,15 & 11,6 & 11,75 & $11,5 \pm 0,31$ \\
\hline & $80 \%$ & 11,65 & 11,7 & 11,65 & $11,67 \pm 0,02$ \\
\hline & $90 \%$ & 12,5 & 12,8 & 13,25 & $12,85 \pm 0,51$ \\
\hline & $100 \%$ & 13,85 & 13,8 & 14,25 & $13,96 \pm 0,24$ \\
\hline & $(+)$ & 21,25 & 21,5 & 21,55 & $21,43 \pm 0,12$ \\
\hline & $(-)$ & - & - & - & - \\
\hline
\end{tabular}

Keterangan: (+) klorampenikol

(-) DMSO

\section{KESIMPULAN}

Hasil uji aktivitas antibakteri EDB menunjukkan adanya aktivitas antibakteri terhadap Bacillus cereus ditunjukan pada konsentrasi 30\%, 60\%, 90\%, 120\% dan 150\%. Sedangkan EKB pada konsentrasi $60 \%, 70 \%, 80 \%, 90 \%$ dan $100 \%$.

\section{DAFTAR PUSTAKA}

Agarwal, M. and Chauhan, S., 2015, Anti-mycobacterial Potential of Crescentia cujete, (Bignoniaceae). International Journal of Advanced Research in Botany, 1, 1, 1-9.

Agitsah, I., Rusmalina, S., Ef, J. dan Jamaludin A., 2014, Penggunaan Antibiotik Pada Terapi Diare Akut Anak Di Instalasi Rawat Jalan Puskesmas Bendan Tahun 2012, Pena Jurnal Ilmu Pengetahuan dan Teknologi, 27, 2.

Ardianti, A. dan Kusnadi, J., 2014, EkstraksiAntibakteri Dari Daun Berenuk (Crescentia cujete Linn.) Menggunakan Metode Ultrasonik, fakultas Teknologi Pangan Universitas Brawijaya Malang, Jurnal Pangan dan Agroindustri, 2, 2, 28-35.

BPOM RI., 2014, Peraturan Kepala Badan Pengawas Obat dan Makanan Republik Indonesia Nomor 17 Tahun 2014 tentang Perubahan atas Peraturan Peraturan Kepala Badan Pengawas Obat dan Makanan Nomor HK.03.1.23.07.11.6662 Tahun 2011 Tentang Persyaratan Cemaran Mikroba dan Logam Berat dalam Kosmetika, Jakarta, Badan Pengawas Obat dan Makanan Republik Indonesia.

Darmadi., 2008, Infeksi Nasokomia Problematika dan Pengendaliannya, Jakarta, Salemba Medika.

Ganiswara, V.H.S., 1995, Farmakologi dan Terapi, Edisi 4, Bagian Farmakologi, Fakultas Kedokteran, Universitas Indonesia, Jakarta. 
Hidayati, D.N., Sumiarsih, C., dan Mahmudah, C., 2018, Standarisasi Non Spesifik Ekstrak Etanol Daun dan Kulit Batang Berenuk (Crescentia cujete Linn), Jurnal Cendekia Eksata, 3, 1, 23.

Kemenkes., 2011, Buletin Jendela Data dan Informasi Kesehatan Situasi Diare di Indonesia, Triwulan II, Vol.2, Kementrian Kesehatan Republik Indonesia.

Rinawati, N.D., 2011, Daya Antibakteria Tumbuhan Majapahit (Crescentia cujete Linn.) Terhadap Bakteri Vibrio alginolyticus, Jurnal Institut Teknologi Sepuluh November.

Rosdiana, D., 2016, Potensi Ekstrak Etanol Kulit Batang dan Daun Berenuk (Crescentia cujete Linn) Sebagai Antibakteri, Skripsi, Tidak dipublikasikan, Departemen Biokimia Fakultas Matematika dan Ilmu Pengetahuan Alam, Institusi Pertanian Bogor, Bogor.

Sa'diyah, M., 2012, Respon Ekstrak Etil Asetat Lumut Hati (Dumortiera hirsuta) sebagai Antimikroba terhadap Escherichia coli, Staphylococcus aureus dan Candida albicans, Skripsi, Departemen Biologi Fakultas Sains dan Teknologi Universitas airlangga, Surabaya. 